\title{
Some Effects of English Loanword Adaptation into SiLozi
}

\author{
Georgina N. Sitali-Mubanga ${ }^{1, *}$ \\ ${ }^{1}$ Department of Languages, School of Humanities and Social Sciences, Kwame Nkrumah \\ University, P.O. Box 80404, Kabwe, Zambia \\ *Corresponding author: Department of Languages, School of Humanities and Social Sciences, \\ Kwame Nkrumah University, P.O. Box 80404, Kabwe, Zambia. E-mail: \\ nandigina@yahoo.co.uk
}

Received: July 25, 2018 Accepted: August 13, 2018 Published: November 12, 2018

doi:10.5296/ije.v10i4.13422ＵRL: https://doi.org/10.5296/ije.v10i4.13422

\begin{abstract}
This study under linguistics, sought to examine the Morphophonological effects of the English loanword adaptation into SiLozi a lingua franca of the Western province of Zambia which is a media of instruction in grades one to three for systematisation. Like many African languages, SiLozi does not have the potential to give equivalents to words of English origin unless through borrowing. Schools being the pivot of development, there was an inconsistency in the same education system concerning the adaptation of English loanwords. The study was carried out in selected primary schools of Mongu district in Zambia. The data were collected with the use of voice recorders during on-going lessons for grades one to three in Creative and Technology Studies, Mathematics, Science, Social Studies and in SiLozi subjects in order to capture all English loanwords used in the SiLozi medium of instruction. The main results revealed that feature changing, deletion, insertion and metathesis phonological rules were applied on the English terms in order to nativise them.
\end{abstract}

Keywords: Adaptation, Generalisation, Loanword, Morphophonology 


\section{MInstitute"}

\section{Introduction}

The objectives of the study centred on identifying the morphophonological effects of English loanword adaptation into SiLozi. Two of the four objectives of the study, have been addressed in this article. Data were collected from already existing loanwords in grades one to three textbooks, unstructured interviews and from recording on-going lessons in Creative and Technology Studies, Mathematics, Science, Social Studies, and from SiLozi. After analysis, data exhibited some morphophonological changes.

\subsection{Background to the Study}

Borrowing due to lack of equivalents of words from other languages can develop the vocabulary of L1. Tarev (2012) says the lack is prompted by absence of mother tongue potential to create or derive words from existing terms in the L1. Additionally, Kashoki (1999: 1) referring to Zambian languages says they "are not sufficiently equipped, whether in the spoken or written form to meet the requirements of an ever changing modern complex society, a society at the same time constantly interacting with a larger international community especially regards those aspects of life which are imported from across national boundaries." The inconsistence is displayed by Mukuni (1991) in nativising some English terms in SiLozi sentences while others are not nativised as in: Flats (apartments) $M a$-flat, President remained the same, Bible was Bibele, member was memba, Post Office was Positi Ofisi, hotel as Hotela, buses as Limbasi and cap (for covering the head) as Kepesi. We can see the unpredictability in the above examples.

\subsection{Statement of the Problem}

The lack of guidelines in schools as to how the loanwords should be adapted is a challenge. If the same education system is using the English borrowed terms variedly, the result is disarray. The morphophonological investigations need to be done by following the SiLozi phonotactics (Note 1) as these loanwords are core to teaching and learning.

\subsection{Objectives of the Study}

The study was guided by the following objectives:

The main objective of the study was to identify the morphophonological effects of English loanword adaptation into SiLozi.

\subsubsection{Specific Objectives}

The study was guided by the following specific objectives:

i) To identify the phonological effects of SiLozi on English loanwords.

ii) To investigate factors which influence the morphology of the English loanwords adapted in SiLozi and the extent of the influence.

\subsection{Research Questions}

The study was guided by the following research questions: 


\section{Macrothink}

i) What are the phonological effects of SiLozi on English loanwords?

ii) Which factors influence the morphology of the English loanwords in SiLozi?

\section{Literature Review and Theoretical Framework}

The following related literature gave me an informed stand.

\subsection{Term Development in Bantu Languages}

Neundorf (1982) and Kostas et al (2006) note the importance of how new words are vital to people who are developing new educational material in a language and say that proposed terms should follow familiar and established patterns of meaning in use. Richard et al (2009) in the study of Geoscience Terminology Development collected science language terms in order to provide geologic data to particular users by using constant expressive terminology. Onyango (2005) scrutinised emerging issues to boost Kiswahili as a medium of instruction in secondary schools. Onyango (2005:222) quotes Abdulaziz (1988) saying that "the major goal of developing terminology should place a premium on schools; they are the most important agent for stabilising language usage". Meaning, schools are the best places to stabilise language hence the use of schools in this study.

\subsection{Phonological Generalisations of the Syllable Structure}

The syllable structure was an important element of the overviews that were made during this study. Kager (2004) refers to the syllable as a major ingredient of phonological generalisations, crucial in defining phonotactic patterns using the OT view. A syllable is "a unit of pronunciation typically larger than a single sound and smaller than a word" (Crystal, 2008:467). The units of pronunciation in SiLozi are; V (vowel), CV (consonant vowel), CCV (consonant, consonant, and vowel) and CCGV (consonant, consonant, glide, and vowel) as below in: 'coin' koini, 'computer' kompyuta and 'desk' ndesiki.

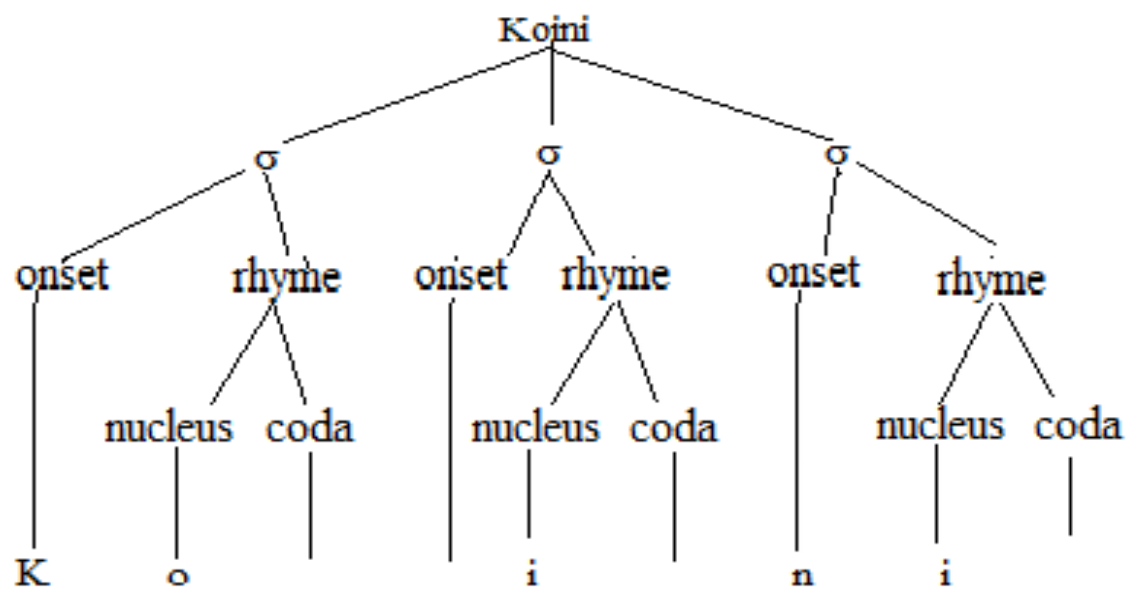

Figure 1. CV, V and CV Syllable Structure 


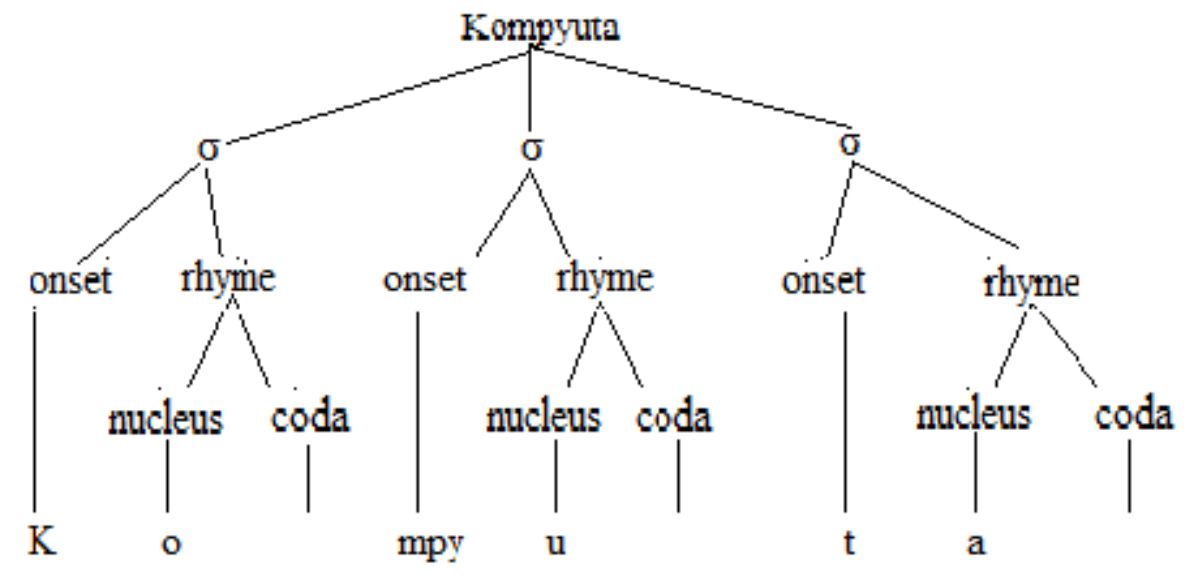

Figure 2. CV, CCGV and CV Syllable Structures

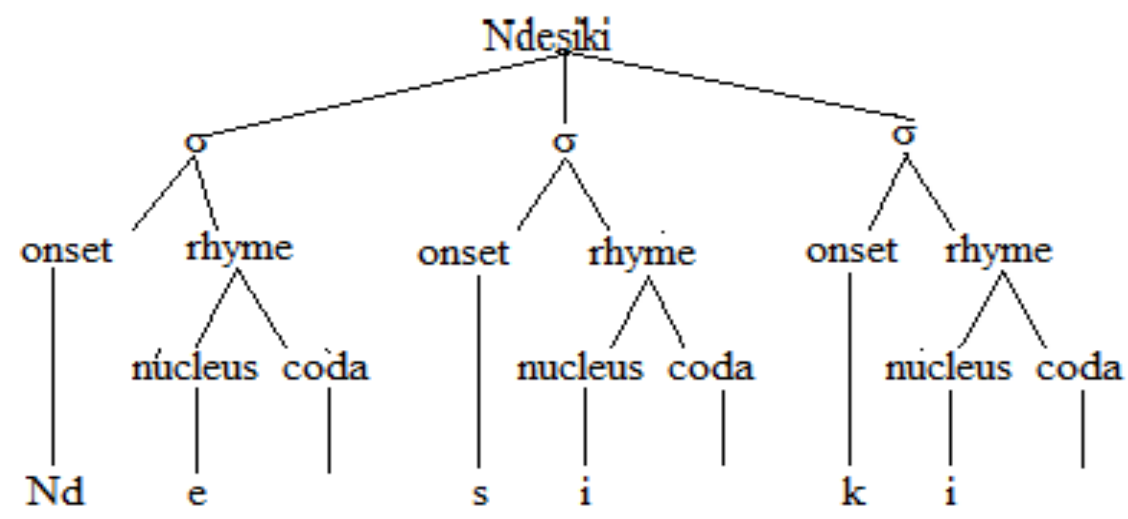

Figure 3. CCV, CV and CV Syllable Structures

Roach (1992) says in English, one could decide whether a particular sound was a vowel or a consonant on phonetic or on phonological grounds which is different in SiLozi as syllables are not decided upon but are in categories. McCarthy (2008) and Dresher (2010) examined the importance of the syllable structure and gave examples accounting for universal preference for syllables to have onsets and to avoid codas citing CV as the least marked syllable type. Concerning phonetics and general linguistics Port (2005) mentions of how the International Phonetic Association has tried to be representative but claims no space for fixed phonetic distinctions as in words whose vowel sounds might be the same but written differently. In SiLozi, all sounds and their forms are regular and do not carry more than one speech sound but $[\mathrm{b}]$ and $[\beta]$ which have the same phoneme $/ \mathrm{b} /$.

\subsection{Morphophonological Generalisations and Integration of Loanwords}

Other scholars studied optimal syllable structures to come up with morphophonological generalisations basing on syllables with fewer violations as in SiLozi. Knight (2013) and Poplack (1988) say L2 words are naturalised into L1 by replacing the sounds in L2 which lack in L1 with L1 nearest similar sound and how they conform to the pattern of L1. Matiki 
(2016: 79) in reference to Chichewa (Malawian and Zambian language) concerning borrowing said "the study of the way loanwords are assigned to various semantic fields has obvious advantages in providing insights into the dynamics of borrowing in particular and language change in general". Littlemore et al., (2010) quote Deconinck et al., (2010) saying that learners associate L2 vocabulary with familiar words from L1 and use L1 to retrieve the L2 word from memory that is, there should be some phonological and graphemic resemblance to the target word in order to do that. Similarly, Ramani et al (2009) in a dual medium Bachelor of Arts degree in SeSotho where SeSotho and English were used in separate programmes citing English loans adapted in SeSotho emphasised the importance of borrowing in learning and teaching for L1 to meet its educational demands. Poplack (1988) as cited in Hasselmo (1969), Mackey (1970), and Poplack and Sankoff (1984) say for borrowed materials to be fully integrated into the recipient language, they must be adapted into the existing patterns of the L1 which this study did.

\subsubsection{Loanwords and Integration of Phonological Constituents}

Nong (2012) investigated loanwords in Northern Sotho by using 100 randomly selected native speakers of Northern Sotho from different places of residence, age, gender and background. The results showed that although most of the participants said they preferred using indigenous words in comparison to loanwords, they still used many English loans.

\subsubsection{Research Gap and the Way Forward}

Fortune (2001) studied CCV syllable types with the tone and length of the five vowels found in SiLozi without talking about loanwords. Further, Coetsem (1988) said language had a constitutional property of stability where certain components or domains were more stable and resistant to change and such a domain was phonology and truly SiLozi exhibited such. Ager (2001) and Rassool (2009) investigated on motives for action on language and discussed strategies, plans and policies of individuals, communities and states. The latter wrote about the importance of education policy concerning the development of how language in education policy impacted on societal developments. Hopson et al., (2005) say the mother tongue as the language of instruction affirms developmental capacity.

Aquaviva (2008), Haspelmath (2009) and Tarev (2012) studied lexical borrowing in different languages showing how loanwords could act as outlets for the transmission and successive integration of new phonemes or inflectional and derivational morphemes into the recipient language forming new words. Tarev (2012) said the evaluation benchmark of a foreign language term is viewed not so much in its origin but how it meets the requirements of the L1 system.

\subsection{Theoretical Framework}

Anfara and Mertz (2015) argue that a theoretical framework is one that sees and makes sense of what to do in the plan and manner of the study. Two linguistic theories; Optimality and Assimilation were used to guide the researcher frame the methodology and the findings. 


\subsubsection{Optimality Theory}

With the use of OT and its view of the syllable structure, the SiLozi phonotactics was used to bring out the optimal patterns of data that were the basis of the morphophonological effects of the English Loanword adaptation into SiLozi. Brasington (2003) explains how the OT model operates in selecting the optimal candidate from the total set of candidates in practice by looking at a familiar collection of the English form of singular and plural forms. Kertesz (2006: 4) said, "In OT universal phonological constraints can be ranked in a language specific fashion, and those that are high-ranked enough will filter out borrowings that cannot ever enter the language (or can do so only after some modification)."

\subsubsection{Assimilation Theory}

Cherry (2018) says the Assimilation theory as first proposed by Piaget concerned the incorporation of new information experiences into already existing ideas and also says Assimilation theory is subjective as it tends to modify experience and fit it in pre-existing knowledge beliefs. In phonology however, Assimilation is a theory by which a sound becomes more like the nearby sound within the word or between words. Assimilation may be regressive or anticipatory or it may be progressive that is; a sound may assimilate a following or a preceding sound respectively. It can be diachronic in the sense that it is dealing with historical or synchronic when it is an active process in a language at a given point in time. I have used Assimilation theory to refer to both diachronic and synchronic processes. The diachronic process refers to the borrowing which used to take place back in the day concerning sounds which were said not to be available in SiLozi such as [b], [d], [g] and [d] which could only be borrowed prior to nasalisation and the synchronic process refers to the current situation where the younger generation is able to adapt the loanwords which have the aforesaid sounds without prenasalising them.

Jurgec (2011) looks at assimilation as an alteration involving two segments which are the target and trigger where the target substitutes the presence of the trigger causing the target to get a property of the trigger. The author gives an example of voicing assimilation for example 'eggs' triggering to 'egz'. This assimilation has been used where the preceding sound of the English plural or similar morpheme such as the word 'beans' or 'bones' is voiced triggering the loanword to change the /s/ to /z/ becoming binizi/mabonizi.

\section{Information about SiLozi Relevant to the Study}

SiLozi a Bantu language of the Niger Congo language family spoken in Barotseland, parts of Angola, Botswana and Zimbabwe and a lingua franca of the Western province (Barotseland) of Zambia and of Namibia's Zambezi region. O'Sullivan (1993) calls it a dominant language group of Southern Africa and a blend of SiLuyana and SiKololo. It came into existence around the $19^{\text {th }}$ century as a result of the Mfecane migration by King Shaka. Abdullah (2007) says Sebitwane; a Mosotho warrior of the Kololo group conquered the Aluyi (Malozi now) and created his Kololo nation, a composite of Sotho and Luyi state which is known as Barotseland. SiLozi has these five short vowels: /a/, /e/, /i/, /o/ and /o/ which are duplicated to 


\section{Macrothink}

indicate length but belong to different syllables. However, different vowels follow each other as below:

a) Baalafi 'nurses/doctors' or 'those who cure' has Ba-a-la-fi (five syllables) as opposed to balafi 'miners' ba-la-fi (three syllables).

Examples of different vowels which follow each other are as follows:

b) Laela 'command, kaizeli 'brother/sister', or maonda 'dowry' and others.

SiLozi has two glides which are /y/ $[\mathrm{j}]$ and /w/ $[\mathrm{u}]$ which can precede any vowel but glide /w/ can never precede vowel /u/ because it is not permissible in SiLozi. Vowel /u/glides to /w/ before vowels /a/, /e/, /i/ and /o/ as in the following examples:

c) Mu-ana 'child' to mwana, mu-eñi 'visitor' to mweñi and others.

Vowel /i/ glides to /y/ when followed by /a/, /e/, /o/ or /u/ as below:

d) Libi-ana to libyana 'clothes', liebela to lyebela 'beautiful' and others,

Coalescent takes place in instances such as in the combination of $/ \mathrm{o} /$ preceded by $/ \mathrm{u} / \mathrm{as}$ :

e) Bu-oko becomes booko 'brain', lu-ongolo becoming loongolo 'chameleon, mu-ongola becomes moongola 'spine' or /a/ and /i/ becoming /ee/ as in;

f) Ma-ito becomes meeto 'eyes' and ma-ino becomes meeno 'teeth'.

\subsection{SiLozi Phoneme and Phonetic Inventories}

Below are the SiLozi phonetic and phonemic inventories.

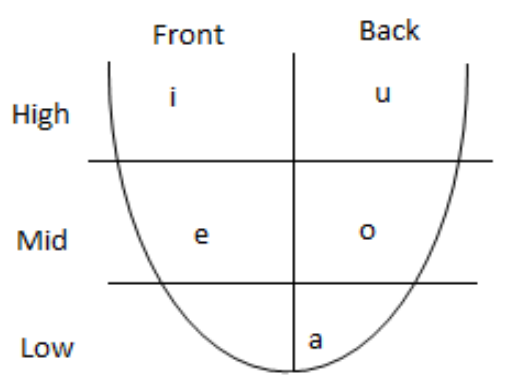

Figure 4. SiLozi Vowel Phonetic and Phonemic Inventory Chart

The inventory in Figure 4 shows single vowels but double vowels are said at the same place and in the same manner. 


\begin{tabular}{|c|c|c|c|c|c|c|c|c|c|c|c|c|c|c|c|c|}
\hline \multirow{2}{*}{$\begin{array}{l}\text { Manner }=- \\
\text { Place } \\
\qquad \\
\bigvee\end{array}$} & \multicolumn{2}{|c|}{ Bilabial } & \multicolumn{2}{|c|}{$\begin{array}{l}\text { Labio- } \\
\text { dental }\end{array}$} & \multicolumn{2}{|c|}{ Dental } & \multicolumn{2}{|c|}{ Alveolar } & \multicolumn{2}{|c|}{$\begin{array}{l}\text { Post } \\
\text { Alveolar }\end{array}$} & \multicolumn{2}{|c|}{ Palatal } & \multicolumn{2}{|c|}{ Velar } & \multicolumn{2}{|c|}{ Glottal } \\
\hline & - & + & - & + & - & + & - & + & - & + & - & + & - & + & - & + \\
\hline Stop/Plosive & $\mathrm{p}$ & $b^{*}$ & & & $\theta^{*}$ & & $\mathrm{t}$ & $\mathrm{d}^{*}$ & & & & & $\mathrm{k}$ & $\mathrm{g}^{*}$ & & \\
\hline Fricative & $\beta$ & & $f$ & $\mathrm{v}^{*}$ & & & s & z & & & & & & & & h \\
\hline Affricate & & & & & & & & & t5 & $d_{3}^{*}$ & & & & & & \\
\hline Nasal & & $\mathrm{m}$ & & & & & & $\mathbf{n}$ & & & & $\eta$ & & & & \\
\hline Lateral & & & & & & & & 1 & & & & & & & & \\
\hline Glide & & $\mathrm{w}$ & & & & & & & & & & $\mathrm{j}$ & & & & \\
\hline
\end{tabular}

Figure 5. SiLozi Consonant Phonetic Inventory

\begin{tabular}{|c|c|c|c|c|c|c|c|c|c|c|c|c|c|c|c|c|}
\hline \multirow{2}{*}{$\begin{array}{l}\text { Manner }=-= \\
\text { Place } \\
\prod\end{array}$} & \multicolumn{2}{|c|}{ Bilabial } & \multicolumn{2}{|c|}{$\begin{array}{l}\text { Labio- } \\
\text { dental }\end{array}$} & \multicolumn{2}{|c|}{ Dental } & \multicolumn{2}{|c|}{ Alveolar } & \multicolumn{2}{|c|}{$\begin{array}{l}\text { Post } \\
\text { Alveolar }\end{array}$} & \multicolumn{2}{|c|}{ Palatal } & \multicolumn{2}{|c|}{ Velar } & \multicolumn{2}{|c|}{ Glottal } \\
\hline & - & + & - & + & - & + & - & + & - & + & - & + & - & + & - & + \\
\hline Stop/Plosive & $\mathrm{p}$ & $b^{*}$ & & & th* & & t & $\mathrm{d}^{*}$ & & & & & $\mathbf{k}$ & $\mathrm{g}^{*}$ & & \\
\hline Fricative & b & & $\mathrm{f}$ & $\mathrm{v}^{*}$ & & & s & $\mathrm{z}$ & & & & & & & & h \\
\hline Affricate & & & & & & & & & c & $d_{3} *$ & & & & & & \\
\hline Nasal & & $\mathrm{m}$ & & & & & & $\mathbf{n}$ & & & & $\tilde{\mathbf{n}}$ & & & & \\
\hline Lateral & & & & & & & & 1 & & & & & & & & \\
\hline Glide & & $\mathrm{w}$ & & & & & & & & & & $\mathrm{y}$ & & & & \\
\hline
\end{tabular}

Figure 6. SiLozi Consonant Phonemic Chart

The consonants in the phonemic chart can be followed by any one of the glides in the onset position but the glides cannot precede any of the above even though $/ \mathrm{y} /$ can precede $/ \mathrm{w} /$ not vice versa. Most phonemes above are preceded by a nasal or they precede a glide in the onset position as in [nd], [ndw], [mb], mbw], [mby], [ng], [ngw] and many others.

\subsection{Morphophonological Effects}

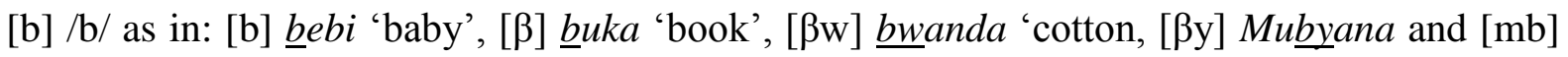
mbalumbu 'bulb'.

[t] /c/ as in: [t] $c a$ 'eat, [ntf] cinca 'change', [ntfw] ncwa 'disease'

[d] /d/ as in: [d] golide 'gold', [nd] Ndesiki, [ndw] $\underline{n d w a}$ 'war.

[f] /f/ as in: [f] feela 'only', [fw] lifwekelo 'harbour'

[g] /g/ as in: [g] gaadeni 'garden', [ng] ngilini 'green', [ngw] singwenjule 'slasher'. 


\section{Macrothink}

[h] /h/ as in: [h] helikopita 'helicopter', [hw] sihwana 'calabash'.

[d]] /j/ as in: [nds] /nj/ nja 'dog' or [d]]/ [ndz] Joni/Njoni 'John'.

[k]/k/ as in: [k] kala 'colour', [nk] nkambe 'boma', [nkw] nkwana 'clay pot'.

[1] /1/ as in: [1] gilaundi 'ground', [1w] lwala 'carry', [ly] lyano 'not true'.

$[\mathrm{m}] / \mathrm{m} /$ as in: [m] Maaci 'March', [mw] mwenyi 'visitor', [my] myaha 'years'.

[n] /n/ as in: [n] na a 'I', [nw] $\underline{n w a}$ 'drink', [ny] nyyunywani 'bird', [nyw] nyunywani 'bird'.

[p] as in: [p] poleji 'porridge', [pw] pwaca 'break', [py] as in pyololo 'whistle', [mpw] mpwe 'onomatopeia', [mpy] mpye 'army'.

[s]/s/ as in: [s] /s/ silei 'sledge', [sw] switi 'sweet', [nsw] nswe 'sweet sorghum'

$[\mathrm{t}] / \mathrm{t} /$ as in: [t] tente 'tent', [nt] tente 'tent', [ntw] Ntwala 'name of a person'.

[j] /y/ as in: [j] yelo 'yellow', [yw] liywalii 'bad day'.

[z] /z/ as in: [z] piza a 'pot', [zw] zwwa 'get out', [nz] $\underline{n z i}$ 'fly', [nzw] manzwi 'words'.

\section{Research Methodology}

The qualitative method with the procedure outlined below was used to get the desired results. Data in form of English loanwords were collected from; recorded lessons, learners' textbooks and from unstructured interviews therefore, the study concerned the pedagogy around English loanwords in SiLozi.

\subsection{Population}

The population on which the results of this study are generalised is grades one to three in the Western province of Zambia.

\subsubsection{Population Sample}

The population sample comprised teachers and learners from three urban and three rural schools (grade one to three) from Mongu district. Eighteen classes were recorded and in all they added to ninety lessons which were five lessons per class. The representatives of the entire population were teachers and learners from grade one to three in Creative and Technology Studies, Mathematics, Science, Social Studies and in SiLozi. See table below.

Table 1. The Number of Schools, Classes and Lessons Observed

\begin{tabular}{ccc}
\hline No. of schools & No. of classes & No. of lessons \\
\hline 6 & 18 & 90 \\
\hline
\end{tabular}




\subsection{The Data}

The data used were from grades one to three recorded lessons, unstructured interviews and from learners' textbooks collected with the help of research assistants.

\subsubsection{Data Collection Methods}

Voice recorders were used to record on-going lessons, we had unstructured interviews and wrote down all loanwords from textbooks for the same grades using pens and notebooks.

\subsection{Ethical Concerns}

I attained research clearance from the University of Dar es Salaam and went on to get informed consent from the participants themselves.

\subsection{Data Analysis}

After data collection, data were transcribed then divided into syllables arranged according to the number of syllables they contained. The SiLozi nominal class system and the syllable structure were used to observe how the loanwords abided with the nominal classes and the latter determined the sound and structure of an English loanword into SiLozi. The Optimality and Assimilation theories were applied to express interaction between phonology and morphology and the assimilation of features to other features.

\subsubsection{Some of the English Loanwords Collected}

\section{$\mathrm{S} / \mathrm{N} \quad$ Loanword}

1. Cekesi

2. Cincana

3. Dokota

4. Egepita

5. Focolo (fosholo)

6. Genda

7. Giledi

8. Jesu

9. Kabati (Kabodi)

10. Kabici (Kabeji)

11. Kukamuna

12. Makaadi

13. Makeki

14. Mushe (Mozesi)

15. Neesi

16. Poso

17. Zigizagi

\section{English Word}

Sickle

Exchange

Doctor

Egypt

Shovel

Gender

Grade

Jesus

Cupboard

Cabbage

To comb derived from the noun 'comb'

Cards

Cakes

Moses

Nurse

Post Office

Zigzag 


\section{Al Macrothink}

Concerning the terms under numbers 1 and 5, we can see that there is metathesis. I can comfortably say that all the [r] have changed to [1]. Fricativisation has occurred in 5, 9, 10 and in 14. In 9 Kabati (Kabodi) 'Cupboard', according to the written loanword, [b] has been softened to $[\beta]$ and $[\mathrm{d}]$ has also been softened to $[\mathrm{t}]$ but the loanword gotten from the oral lessons does not change the pronunciation even though the structure or rather the spelling has changed. As in Number 10 Kabici (Kabeji) 'Cabbage', the textbook loanword has softened [b] to [ $\beta$ ] and [d] to [t] but as in the learners' type of borrowing, it has not changed the sounds [b] and [d]]. In Number 14 Mushe (Mozesi) 'Moses', [z] has been softened to a voiceless alveolar stop [s] and just like in other loanwords where phonemes or sounds are either deleted or inserted, there has been an insertion of $[\mathrm{h}]$ between $/ \mathrm{s} /$ and /e/ and the final $/ \mathrm{s} / \mathrm{has}$ been deleted.

There is also an element of blending and clipping in some of the loanwords such as in number 8 and 16 Jesu 'Jesus' and Poso 'Post Office'. As for verbs which have been borrowed from English, some of them have been formed from other verbs and some from nouns. Let us take for example number 11 which is a verb Kukamuna 'to comb' is derived from the term kama 'comb' (noun). This data is also telling us that learners did not prenasalise [b], [d], [g] and [j] as we can see even from textbook loans in numbers $3,4,6,7$, 8, 10, 12 and 17 that not all [b], [d], [g] and [j] sounds were prenasalised meaning that the prenasalisation of the aforementioned sounds are not only rare in the current generation's pronunciation but in the textbooks too. We can also note that in number 12 Makaadi 'Cards' and 15 Neesi 'Nurse, the vowels preceding [r] have been lengthened and [r] has been deleted.

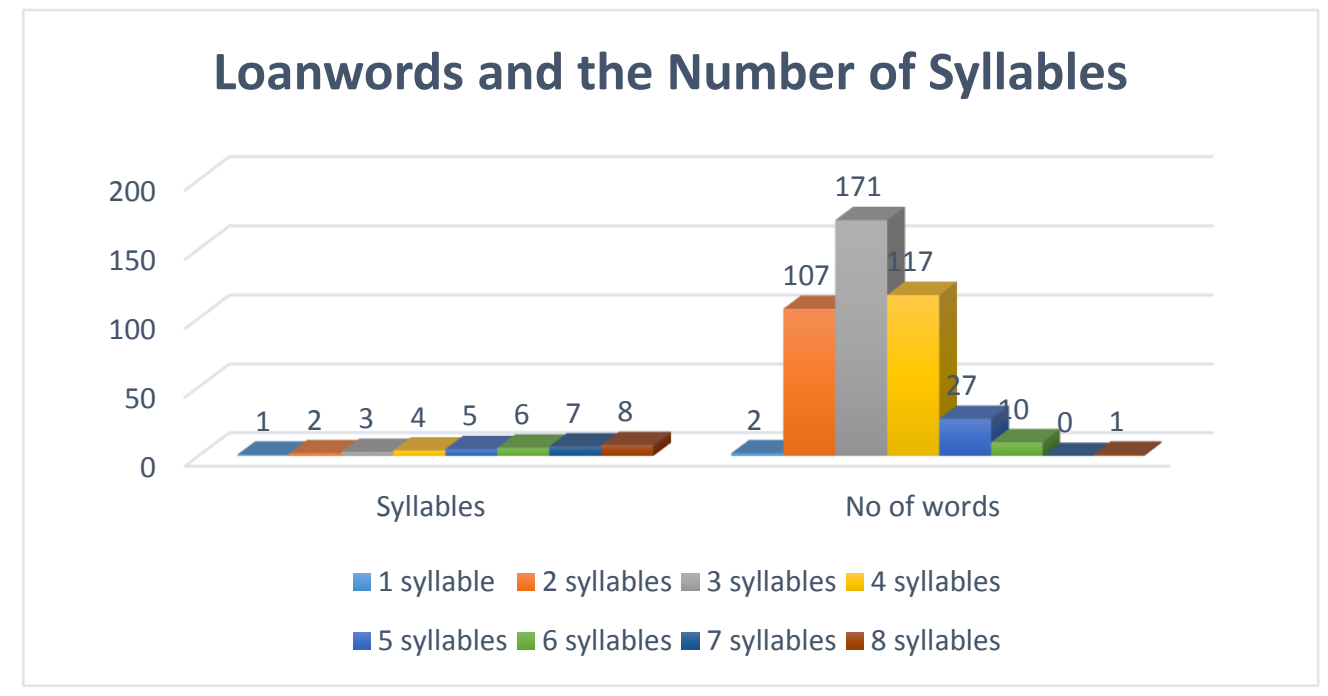

Graph 1. Loanwords and the Number of Syllables

The number of loanwords collected and the syllables they contained is reflected in Graph 1 . One-syllable loans were only 'no' and 'go'. No adjustment was done to them. 


\subsubsection{Interpretation of Patterns Emanating from the Data}

Conferring to the data presented above, some sounds and phonemes have changed, incorporated, deleted or reshuffled in order for the English loanwords to fit into the SiLozi phonology. Below is an amplification of how some units were converted in the loanwords.

a) /a/ can either be converted to /e/ or /o/ in the word medially as below:

i) /a/ to /e/ Babby be bi, bare beya, change cenji.

ii) /al/ [๑:] converted to /o/ [0]. The sound [०:] has been shortened in SiLozi as in: Ball Bola/Mbola, Chalk choko/choki

We conclude that when /a/ precedes / $/$ / the sound made is /o/ [0].

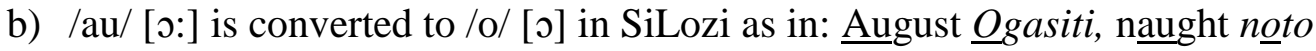

c) $/ \mathrm{b} /[\mathrm{b}]$ converted to $/ \mathrm{mb} /[\mathrm{mb}]$ or $/ \mathrm{b} /[\mathrm{b}]$. The voiced bilabial plosive [b] takes the form of $/ \mathrm{b} /$ or $/ \mathrm{mb} /$ in writing and it is pronounced as in the words below: Ball $\underline{\text { bola }}$ mbola and $\underline{b}$ and $\underline{b} a n d i / \underline{m b}$ andi. $[\mathrm{b}]$ and $[\mathrm{mb}]$ can occur in the same environment.

d) As for $/ \mathrm{b} /$ converting to $/ \mathrm{p} /, / \mathrm{p} /$ [p] can occur in the same environment as [b] or [mb] as

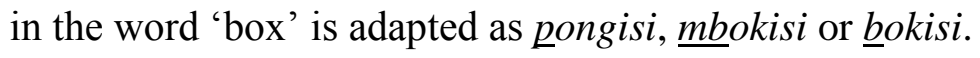

e) $/ \mathrm{c} /[\mathrm{k}]$ converted to $/ \mathrm{k} /[\mathrm{k}]$ or $/ \mathrm{c} /[\mathrm{s}]$ as in:

Scotch cart sikocikala, class kilasi, Rebbecca Labeka. In 'Rebecca', one /c/ is deleted because it is not permissible in SiLozi.

f) $/ \mathrm{c} /[\mathrm{s}]$ converted to /s/ [s]: as in central senturalu, office ofisi or police polis $\underline{i}$

g) $/ \mathrm{ch} /[\mathrm{t}]$ converted to $/ \mathrm{c} /[\mathrm{t}], / \mathrm{j} /[\mathrm{d}]$ ] and to $/ \mathrm{k} /[\mathrm{k}]$ as in butchery [botfori] Buca $[\mathrm{but} \Lambda \Lambda$,

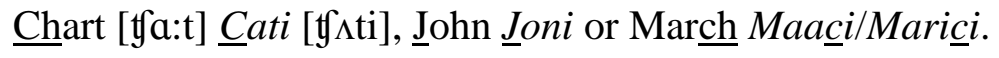

$[\mathrm{t}] / \mathrm{Ch} /$ in SiLozi is used word initially in proper nouns and $/ \mathrm{c} /$ in others.

h) $/ \mathrm{ch} /[\mathrm{t}]$ when preceded by /n/ [n] is converted to /nj/ [ydz]: Launch (boat) lonjii.

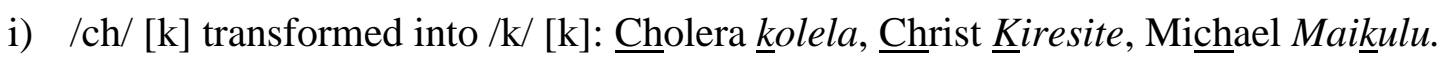

j) Owing to the supposedly lack of the voiced alveolar plosive [d], the sound is transmuted into a voiced alveolar plosive nasal complex /nd/ [nd] as below:

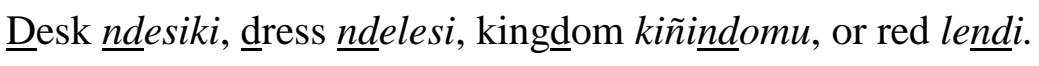

k) /e/ [i] transmuted into /i/ [i]

/e/ transformed into /i/ [i]. The /e/ phoneme at the end of some English terms does not bear the sound [i] but when adapted into SiLozi, the sound [i] is included. The transmutation of /e/ into /i/ according to the data only happened in mid and final word positions as in Change

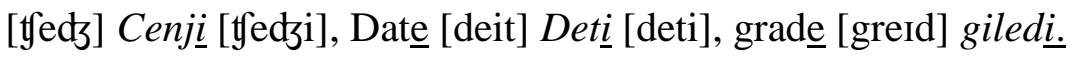

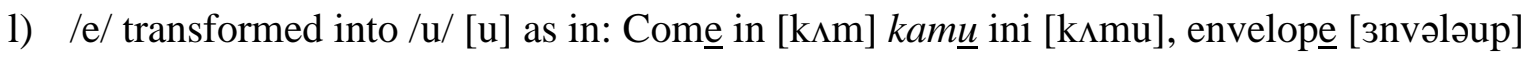


ingilop $\underline{u}$.

m) /ea/ [3] converted to /e/ [e] in the middle position words as in: Bread buledi, break bulekki, head hedi and weak wi $\underline{i} i$

n) /ee/ [r:] converted to /i/ [i]. The long /ee/ [r:] is shortened when adapted into SiLozi. The alteration occurs mostly in mid and final word positions as in:

Canteen kantini, green gilini or three thiri.

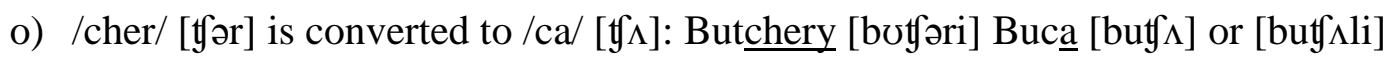

p) /er/ [ər] is converted to /a/ $[\Lambda]$ in mid or final word position as in: Canter kanta, exercise ekisasaizi or ruler lula.

q) /ey/ [i] transformed into /i/ [i] as below: donkey donki or key kii.

r) $/ g /$ converted to $/ \mathrm{j} /$. This is more or less like in 1 ) where the last phoneme does not have a phonetic symbol: Bridge [bridz] buliji [bulidzi], cabbage [kabidz] kabeji [kıbedzi], message meseji, porridge poleji

s) In English loanwords adapted into SiLozi, /gh/ is deleted before /t/ in all borrowed words as in the following terms: Eight eiti, light laiti or lighter laita.

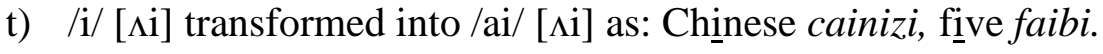

u) /ir/ [ə:] converted to /e/ [e]. /ir/ unlike /or/, /er/ and /ar/ does not become a long vowel as in: Circle sekulu or thirty theti/seti.

v) /o/ [əu] converted to /a/ $[\Lambda]$ as in the following terms: Pope Papa.

w) $/ \mathrm{o} /[\Lambda]$ converted to $/ \mathrm{a} /[\Lambda]$ : Pontoon pantunu or Southern Sauzeni

$\mathrm{x}) / \mathrm{o} /[\mathrm{a}]$ converted to /a/ $[\Lambda]$ as in: Rounding laundini or town tauni.

y) $/ \mathrm{oo} /[\mho]$ converted to $/ \mathrm{u} /[\mathrm{u}]$ occurs in mid-word positions as in: Book b $\underline{u} k a$, good $g \underline{u} d u$ or toothbrush tusibulasho.

z) /or/ [ər] converted to /a/ $[\Lambda]$ takes place in mid or final word positions and not in initial positions as in: Doctor Dokota or Taylor tela.

aa) /or/ [o:] assimilated (progressively) to /a/ $[\Lambda]$ or $[0:]$ as in 'torch': Torch taci (tooci) by learners.

bb) /ph/ [f] converted to /f/ [f]: Phone foni, Metamorphism metamofomizimu.

cc) /q/ [k] converts to /k/ [k] as: Question kwesheni or Mosque mosiki 


\section{1) Macrothink}

International Journal of Education

ISSN 1948-5476

2018, Vol. 10, No. 4

dd) /r/ [r] becomes /1/ [1] when not preceded by a vowel other than in vowel /i/ as in: Lorry looli or relay lilei but when $/ \mathrm{r} /[\mathrm{r}]$ is preceded by a vowel, the vowel is lengthened in mid (mostly) or final word position as in Cards makaadi or horse hoosi. These are occurrences of progressive assimilation.

ee) /s/ [z] assimilates (progressively) to /z/ [z] when preceded by a voiced sound as in Beans binizzi or Cells seluzi $i$ but it remains as $[\mathrm{s}] / \mathrm{s} /$ as in 'sets' maseti.

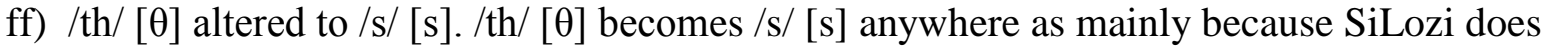
not have the theta $(\theta)$ sound as in: Face cloth kulos $i$ or teeth brush tisibulasho.

$\mathrm{gg}$ /th/ [ð] altered to /z/ [z] if /th/ is preceded by a voiced sound as in Southern sauzeni

$\mathrm{hh}) / \mathrm{u} /[\partial]$ transformed into $/ \mathrm{a} /[\Lambda]$ as in abacus abakasi in initial or mid word position.

ii) $/ \mathrm{u} /[\Lambda]$ transformed into $/ \mathrm{a} /[\Lambda]$ as in the terms below: Button batani or rubber laba .

jj) $/ \mathrm{u} /[\Lambda]$ converted to $/ \mathrm{a} /[\Lambda]$ as in 'magnesium' maginiziamu.

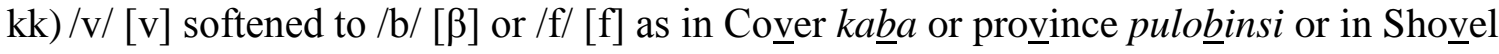
foshololfocolo (metathesis too).

11) $/ \mathrm{w} /[\mho]$ transformed into /u/ [u]: Brown bulauni or town tauni.

$\mathrm{mm}) / \mathrm{w} /[\mathrm{u}]$ transformed into /u/ [u]: Mathew Mate $\underline{u}$ or New ny $\underline{u}$.

$\mathrm{nn}) / \mathrm{x} /[\mathrm{ks}]$ transmuted into /kis/ [kisi]: Amoxil amokisilu or next ne kisiti.

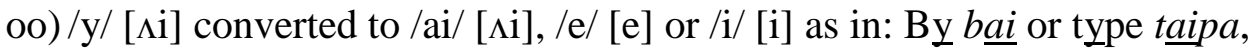

/y/ [i] converted to /e/ [e] as in Egypt Egepita or fifty fifite and /y/ [i] converted to /i/ [i]:

Butchery bucali or relay lile $\underline{\text {. }}$.

\subsubsection{SiLozi Nominal Classes and Loanwords}

Nominal classes are a distinctive feature in Bantu languages and SiLozi being a Bantu language, they are part. SiLozi has twenty (20) nominal class prefixes as below. The noun classes express singular and plural prefixes of nouns and things such as kinship terms, quality of nouns or adjectives and they indicate locative prefixes. Likewise, they include pejorative and diminutive prefixes. Mwisiya (1991) wrote twenty-two (22) nominal class prefixes which comprised two Ur-Bantu prefixes and these have no counterpart in the SiLozi nominal class system and no loanwords were mentioned. Not all loanwords fitted squarely in the system. Owing to that I suggested classes $9 \mathrm{~b}$ and 10b. The plural of the English loanwords borrowed into SiLozi as we can see below can fit in 9a as they have a zero morpheme for singular but then they have no prefix for plural. Borrowed words used in a diminutive and pejorative manner, fit well in nominal classes 12, 13, 19 and 20. 
Table 2. Nominal Classes

\begin{tabular}{|c|c|c|c|}
\hline Class & Prefix & Example & Function \\
\hline 1 & Mu- & 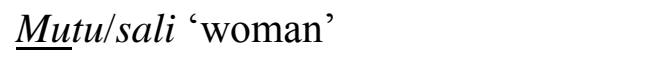 & Singular of class 2 . \\
\hline $1 \mathrm{a}$ & $\varnothing$ & Ndate/malume 'father/uncle'. & Kinship singular form. \\
\hline 2 & Ba- & Batu 'persons', basali 'women'. & Plural of Class 1. \\
\hline $2 \mathrm{a}$ & Bo- & Bondate, bomalume & Honorific form of Class la \\
\hline 3 & Mu- & 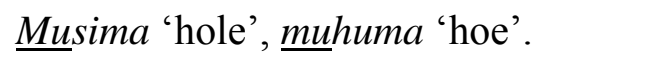 & Singular of class 4 . \\
\hline 4 & mi- & 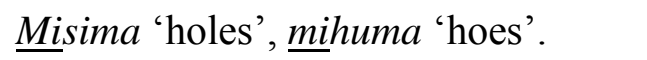 & Plural of Class 3. \\
\hline 5 & li- & Lizoho/ito 'hand/egg' & Singular form of class 6 \\
\hline 6 & ma- & Mazoho 'hands', meeto 'eyes'. & Plural prefix of Class 5 \\
\hline 7 & si- & 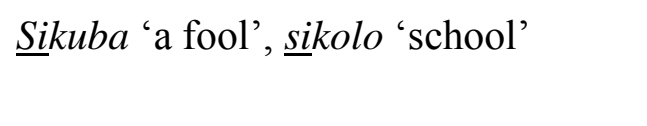 & $\begin{array}{l}\text { Singular Class } 8 \text { of things or state of } \\
\text { being. }\end{array}$ \\
\hline 8 & li- & 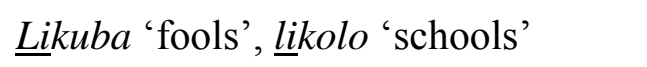 & Plural prefix of Class 7. \\
\hline 9 & n- & $\underline{N}$ dongo 'groundnuts', & Counterpart of Class 10. \\
\hline \multirow[t]{2}{*}{$9 \mathrm{a}$} & $\varnothing$ & Nja 'dog', komu 'cow'. & Singular of $10 \mathrm{a}$ first row. \\
\hline & & Donkii 'donkey', fosholo 'shovel' & Singular of 10 a second row. \\
\hline 9b & $\varnothing$ & Dokota 'doctor', neesi 'nurse'. & Singular of $10 \mathrm{~b}$. \\
\hline 10 & n- & Ndongo 'groundnuts' & Plural of Class 9. \\
\hline \multirow[t]{2}{*}{$10 \mathrm{a}$} & li- & 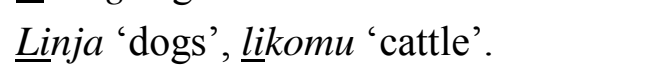 & Plural of Class 9a first row. \\
\hline & & Lidonkii/fosholo 'donkeys/shovels' & Plural of 9a second row. \\
\hline $10 \mathrm{~b}$ & ma- & Madokota/neesi 'doctors/nurses'. & Plural prefix of $9 \mathrm{~b}$ loanwords \\
\hline 11 & lu- & Lunyaltimbo 'cruelty/hatred'. & State of being starting with $l u$ \\
\hline 12 & ka- & 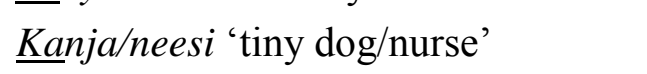 & Singular diminutive of Class 13 \\
\hline 13 & tu- & Tuneesi/nja; 'tiny nurses/dogs' & Plural diminutive of Class 12 \\
\hline 14 & bu- & Bunde 'beauty', bunsu 'black'. & State of being beginning with $b u$ \\
\hline 15 & ku- & 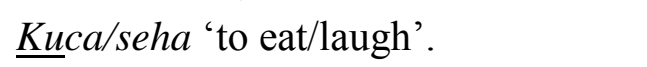 & To infinitive forms \\
\hline 16 & fa- & Fande 'outside', $f a$ 'here' & Locative prefix 'on' \\
\hline 17 & kwa- & 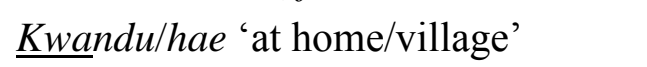 & Locative of place e.g. 'at' \\
\hline 18 & mwa- & Mwazebelliito 'in the ear/eye' & Locative prefix denoting 'in' \\
\hline 19 & si- & Siina/neesi 'ugly/big man/nurse' & Singular pejorative of Class 20 \\
\hline 20 & bi- & $\begin{array}{l}\text { Biina ugly/big boys, } \underline{\text { bineesi }} \\
\text { 'ugly/big nurses' }\end{array}$ & Pejorative plural of Class 19 \\
\hline
\end{tabular}

\subsection{Implications of the Findings}

According to the arrays which stood out, I married the objectives of the study and their research questions to the findings by identifying the phonological effects of SiLozi on the loanwords which influenced their morphology. 


\section{MInstitute"}

\section{Summary, Conclusions and Recommendations}

\subsection{Summary}

The use of loanwords in grades one to three is unavoidable as there are some technical words which are not found in SiLozi. The main objective of this study was to identify the morphophonological effects of the English loanword adaptation into SiLozi. To do that, 435 loanwords were collected from schools and I used the objectives of the study to measure the morphophonological effects of the adaptation of the collected loanwords into SiLozi for standardisation. Data were transcribed then analysed and the loanwords from urban schools varied insignificantly from rural schools. Arrays such as some phonemes converting to other phonemes due to the SiLozi phonotactics and due to SiLozi being a tonal and phonemic language occurred. Some sounds which were originally voiced in English became voiceless in SiLozi and others were deleted or inserted depending on SiLozi phonotactics. Using the arrays that surfaced, generalisations were made.

\subsection{Conclusion}

The data revealed patterns that could be followed, and these patterns need to start in schools as they are the pivot of development. Likening what was written in the learners' textbooks to what the learners were saying in class, the sound and form used in their textbooks was not compatible with the learners'. We conclude that the phonology and the morphology of SiLozi are applied on the English terms by assimilation and by the use of phonological rules such as insertion, deletion, feature changing and metathesis. We further conclude that, the English plural and singular markers are discarded and the SiLozi ones are used word initially although in fewer cases, the English plural form can be used together with the L1 plural markers.

\subsection{Recommendations}

After data analysis, this study recommends the following;

\subsubsection{Recommendations for Further Research}

i) Studies examining loanword nativisation from different specialised fields be carried out to solidify field specific loanword adaptation process.

ii) Bilingual dictionaries relating to technical loanwords should be carried out.

\subsubsection{Policy Recommendation}

i) All teacher trainees should take a course in loanword adaptation for normalisation.

ii) Explore public awareness through different Medias. 


\section{Macrothink}

International Journal of Education

ISSN 1948-5476

2018, Vol. 10, No. 4

\section{References}

Abdullah, M. (2007). Sebitwane/Bibliography-African King Britannica.com. Britannica.com. Retrieved from https://googleweblight.com/i?u=https://www.britannica.com/editor/The-Editors-of-Ency clopaedia-Britannica//4419\&hl=en-zm\&tg=27\&pt=1

Ager, D. (2001). Motivation in Language Planning and Language Policy. Clevedon: Multilingual Matters.

Anfara, Vincent, A., \& Mertz, N. (Eds) (2015). Theoretical Frameworks in Qualitative Research (2nd Ed.). USA: SAGE Publishers.

Aquaviva, P. (2008). Lexical Plurals: A Morphosemantic Approach (URL: https://global.oup.com/academic/product/lexical-plurals-ISBN-9780999534210?cc=na \&lang=en\&). New York: OUP.

Brasington, R. (2003). Constraint Based Morphology: Coursework Notes 2 - Optimality Theory. UK: The University of Reading.

Cherry, K., (2018). The Importance of Assimilation in Adaptation. Retrieved from https://www.verywellmind.com/what-is-assimilation

Coetsem, F. (1988). Loan Phonology and the Two Transfer Types in Language Contact. Holland: Foris Publications.

Crystal, D. (2008). A Dixctionary of Linguistics and Phonetics. Oxford: Blackwel Publishing.

Dresher, E. (2010). The Contrastive Hierarchy in Phonology. Cambridge: CUP. https://doi.org/10.1017/S0952675710000278.

Fortune, G. (2001). An outline of Silozi Grammar. Lusaka: KKF.

Haspelmath, M., \& Tadmor, U. (Ed.) (2009). Lexical Borrowing: Concepts and Issues. Berlin: De Gruyter.

Hopson, B. U. (2005). Languages of Instruction for African Emancipation: Focus on Post-Colonial Contexts and Considerations. Cape Town: CASAS.

Jurgec, P. (2011). 'What is Assimilation'. Retrieved from https://www.google.com/search?q=Peter+Jurgec+what+is+assimilation\%3F\&oq=Peter+ Jurgec + what + is $=$ assimilation $\% 3 F \& a q s=$ mobile-gws-lite

Kager, R. (2004). Optimality Theory. Cambridge: CUP.

Kashoki, M. E. (1999). Loanwords in Silozi, Cinyanja and Citonga. Ndola: Mission Press.

Kertesz, Z., (2006). The Even Yearbook 7: 'Approaches to the Phonological Analysis of Loanword Adaptation. Eotos Lorand University Budpest.

Littlemore, J. G. (2010). Applied Cognitive Linguistics in Second Language L Vol. 23 . Amsterdam: John Benjamin Publishing. 
Matiki, A. J. (2016). Patterns of Borrowing in Chichewa. Journal of the Linguistics Association of Southern African Development Community Universities, 4(4).

McCarthy, J. (2008). Doing Optimality Theory: Applying Theory to Data. USA: Blackwell Publishing.

Mukuni, R. M. (1991). SiLozi-English Phrase Book. Lusaka: KKF.

Mwisiya, M. W. (1977). Introduction to SiLozi Grammar. Lusaka: NECZAM.

Neundorf, A. (1982). Terminology Development in Navajo. International Journal of American Linguistics, 48(3), 271-276. https://doi.org/10.1086/4657

Nong, S. G. M. (2012). Loan Words versus Indigenous Words in Northern Sotho- A Lexicographic Perspective. Lexiko, 12(AFRILEX -reeks/series 12), 1-20. https://doi.org/10.5788/12-0-758.

Onyango, O. J. (2005). Issues in National Language Terminology Development in Kenya. Oxfora Journals (n.d.). Swahili Forum, 219 - 234.

O'Sullivan, O. (1993). English - Silozi Dictionary. Lusaka: ZEPH.

Poplack, S., David, S., \& Christopher, M. (1988). The Social Correlates and Linguistic Process of Lexical Borrowing and Assimilation. https://doi.org/10.1515/Ling.1988.26.147

Port, F. R. \& Leary, A. P. (2005). Against Formal Phonology. Linguistic Society of America: Language, $\quad$ Vol. $\quad 81, \quad$ No 4 (December 2005), 927-964. http://www.jstor.org/stable4490023.

Ramani, E., Kekana, T., Modiba, M., and Joseph, M. (2009). Terminology Development Versus Concept Development through Discourse: Insights from a Dual Medium BA Degree. https://doi.org/10.2989/1607361070948657.

Rassool, N. (2009). Global Issues in Language, Education and Developments: perspectives from Post-Colonial Countries. Great Britain: Cromwell Press Ltd. ISBN: 9781853599514.

Richard, S. E. (2009). Geoscience Terminology Development for the National Geologic Map Database.

Roach, P. (1992). English Phonetics and Phonology. Cambridge: CUP.

Tarev, B. V. (2012). Lexical Borrowings: Linguistic and Didactic Aspects. Moscow: National Research University.

\section{Note}

Note 1. Phonotactics according to Crystal (2008: 366) is, "a term used in phonology to refer to the sequential arrangements (or tactic behaviour) of phonological units which occur in a 


\section{Macrothink}

language."

\section{Copyright Disclaimer}

Copyright for this article is retained by the author(s), with first publication rights granted to the journal.

This is an open-access article distributed under the terms and conditions of the Creative Commons Attribution license (http://creativecommons.org/licenses/by/3.0/). 